\title{
ARTICLE
}

\section{Population dynamics of the swimming crabs Callinectes (Portunidae) components of shrimp bycatch in the eastern coast of the Gulf of California}

\author{
Dinámica poblacional de jaibas Callinectes (Portunidae) componentes de la fauna de \\ acompañamiento del camarón en la costa oriental del Golfo de California \\ Juana López-Martínez ${ }^{1}$, Leonor López-Herrera², \\ J. Eduardo Valdez-Holguín ${ }^{2}$ and Carlos H. Rábago-Quiroz ${ }^{3}$
}

${ }^{1}$ Centro de Investigaciones Biológicas del Noroeste, S.C. Unidad Sonora, Campus Guaymas. Km. 2,35, Carretera a Las Tinajas, S/N, Colonia Las Tinajas, C.P. 85465, Guaymas, Sonora, México. jlopez04@cibnor.mx

${ }^{2}$ Departamento de Investigaciones Científicas y Tecnológicas de la Universidad de Sonora, Luis Donaldo Colosio S/N, entre Sahuaripa y Reforma, Colonia Centro, C.P. 83000, Hermosillo, Sonora, México

${ }^{3}$ Instituto Nacional de Pesca. Centro Regional de Investigación Pesquera, Carretera a Pichilingue, Km. 1 S/N, Colonia El Esterito, C.P. 23022, La Paz, Baja California Sur, México

\begin{abstract}
Resumen.- Se reportan por primera vez aspectos de la dinámica poblacional de 3 especies del género Callinectes: C. arcuatus, C. bellicosus y $C$. toxotes capturadas incidentalmente por la flota camaronera en la costa oriental del Golfo de California entre 10 y 77 m de profundidad de septiembre 2004 a marzo 2005. Se analizaron crecimiento, longevidad, patrón de reclutamiento, tasas de mortalidad y explotación para las 3 especies. Además, se realizó una comparación de tallas entre los organismos capturados por la flota camaronera y la flota ribereña. Callinectes arcuatus $(n=737)$ fue más abundante que las otras 2 especies ( $C$. bellicosus, $n=291$ y $C$. toxotes, $n=344$ ). Se detectaron diferencias significativas entre las distribuciones de tallas de $C$. arcuatus y $C$. bellicosus; la flota camaronera extrae mayormente organismos de ambas especies entre 50 y $120 \mathrm{~mm}$ ancho de caparazón (AC), mientras que la ribereña de 75 a $155 \mathrm{~mm}$. Los parámetros de crecimiento fueron moderados $\left(L_{\infty}=160,173\right.$ y $168 \mathrm{~mm}$ y K=1,1, 1,3 y 0,9 año-1 para $C$. arcuatus, C. bellicosus y $C$. toxotes, respectivamente), con una longevidad estimada para las 3 especies de 4 años. El patrón de reclutamiento muestra un periodo continuo, con un máximo entre mayo y agosto. La tasa de explotación no indica un grado significativo de sobrexplotación para ninguna especie. Se encontraron diferencias en parámetros de la dinámica poblacional (tallas, crecimiento) de estas especies basados en datos de capturas comerciales y los obtenidos con datos de capturas incidentales. Es importante realizar un análisis donde se incluyan los dos tipos de información para un adecuado manejo pesquero de estos recursos.
\end{abstract}

Palabras clave: Callinectes, dinámica poblacional, fauna de acompañamiento, Golfo de California

\begin{abstract}
Population dynamics of 3 Callinectes species: C. arcuatus, C. bellicosus, and C. toxotes are reported for the first time as incidental shrimp bycatch samplings captured in the eastern Gulf of California in a range from 10 to $77 \mathrm{~m}$ in depth from September 2004 to March 2005. Growth, longevity, recruitment pattern, mortality (natural, total, and by fishing), and exploitation rate were analyzed. Also, size comparison among the organisms captured by the shrimp and artisanal fishing fleets was calculated. Callinectes arcuatus $(n=737)$ was more abundant than the other two $(C$. bellicosus, $n=291$ and $C$. toxotes, $\mathrm{n}=344)$. Significant differences were shown between size distribution of $C$. arcuatus and $C$. bellicosus captured by the 2 fleets; the shrimp fleet extracted mainly organisms in sizes ranging from 50 to $120 \mathrm{~mm}$ in carapace width (CW), while the artisanal fleet extracted sizes from 75 to $155 \mathrm{~mm}$ in $\mathrm{CW}$ from both species. Growth parameters were moderate $\left(\mathrm{L}_{\infty}=\right.$ 160, 173, and $168 \mathrm{~mm}$; K= 1.1., 1.3 and 0.9 year $^{-1}$ for C. arcuatus, C. bellicosus, and C. toxotes, respectively), estimating a 4year longevity for the 3 species. The reproductive recruitment pattern showed a continuous period with a peak from May to August. The exploitation rate did not show a significant degree of overexploitation for any of the species. There are some differences in the parameters of population dynamics (sizes, growth) of this species based on data from commercial captures and those obtained with data of incidental captures. It is important to perform an analysis including both types of information for an adequate fishery management of these resources.
\end{abstract}

Key words: Callinectes, population dynamics, bycatch fauna, Gulf of California 


\section{INTRODUCTION}

Swimming crab species of the genus Callinectes Stimpson, 1860 are distributed along the Neotropical Atlantic, Eastern Tropical Pacific, and the Tropical West Africa coast (Williams 1974). Fischer \& Wolff (2006) mention the existence of 14 Callinectes species in both American coasts, of which 11 are registered in tropical and subtropical waters.

These crabs inhabit the coastal areas and depend on lagoon and estuary systems. They have a complex life cycle comprising planktonic, nektic, and benthic stages, which take place in these systems and close to the marine area (Ramírez-Félix et al. 2003). Swimming crabs have a priority role in the trophic web and are characterized by great recruitment, sexual maturity at an early age, accelerated growth, high rates of natural mortality, and a short life cycle (Van Engel 1990).

Ecology, life cycle, and population dynamics of these crabs in the eastern Pacific are poorly understood. Lack of knowledge on these resources that constitute the basis of important commercial fisheries in several regions of the eastern Pacific has practical implications. One example is the crab fishery that has been performed in Mexico for more than 20 years and is one of the most important as to generating jobs and currency. In 2010, this fishery had a value of 239 million pesos, representing $2.21 \%$ of the fishery production value in the country (SAGARPACONAPESCA 2011). The production of this resource was 20,262 ton live weight, of which 10,758 ton corresponded to the Pacific coast and 9,505 ton to the Gulf of Mexico and the Caribbean Sea. From the Pacific side, the production of the Gulf of California that stands out is a contribution of the states of Sinaloa (6,107 ton) and Sonora (4,073 ton) (SAGARPA-CONAPESCA 2011). The captures in the Gulf of California are composed mainly of 3 species: green crab (Callinectes bellicosus) that stands out for its larger volumes compared with the blue ( $C$. arcuatus) and the giant (C. toxotes) swimming crabs.

To capture these species off the Gulf coastline states, 2 types of fishing gear are used: (1) hoops - metal structures with a woolen cloth mesh (Sinaloa and Nayarit); and (2) metal fishing traps - cube-shaped, hexagonal metal mesh plastic-coated, with 2 entrances and a cylinder in the middle for bait (rest of the Gulf) (Ramírez-Félix et al. 2003, DOF 2006) $)^{1}$.
Works performed on Callinectes crabs in the Gulf of California have dealt mainly on size, longevity, and growth (Nevárez-Martínez et al. 2003, Hernández \& ArreolaLizárraga 2007, Reyes-Benítez et al. 2007, RodríguezDomínguez et al. 2012), reproductive period (Paul 1982a, Nevárez-Martínez et al. 2003), abundances and seasonal capture (Villarreal-Chávez 1992, Escamilla-Montes 1998, Molina-Ocampo et al. 2006), ecology (Arreola-Lizárraga et al. 2003, Ramírez-Félix et al. 2003, Molina-Ocampo et al. 2006), and population genetics (Ramírez-Félix et al. 2003, Pfeiler et al. 2005). These works have focused exclusively on analyzing the information obtained in commercial captures of artisanal fishery without knowing how the population fraction found in deeper areas is integrated.

Considering that a migration from shallow waters to open seas occur in Callinectes spp. (with reproductive purposes) (Molina-Ocampo et al. 2006), away from where the commercial captures of artisanal fishery are obtained and due to the high selectivity of the capture methods used (traps), it is possible to consider the hypothesis that a portion of the population is not available for artisanal fishery. Therefore, some aspects of the population dynamics (mortality, growth, exploitation, etc.) have been partially addressed in the works cited above, but knowing all the parts of the population dynamics of these resources is imperative for proper fishery management.

From an economic and ecological point of view, Callinectes crabs are important in the Mexican Pacific and specifically in the Gulf of California. However, some aspects are still unknown, such as mortality rates, exploitation level, and sizes, among other aspects of these species incidentally captured in shrimp trawling. Therefore, the objective of this work was to study the population dynamics of $C$. arcuatus, C. bellicosus, and C. toxotes in the eastern Gulf of California where mortality rates and exploitation level of these 3 species captured incidentally by shrimp trawling fleet at depths from 10 to $77 \mathrm{~m}$ are assessed for the first time.

\section{MATERIALS AND METHODS}

\section{STUDY AREA AND SAMPLING DESIGN}

The study area comprises the eastern portion of the Gulf of California between $21^{\circ} 13^{\prime} 37^{\prime \prime} \mathrm{N}, 105^{\circ} 16^{\prime} 06^{\prime \prime} \mathrm{W}$, and

${ }^{1}$ DOF. 2006. Norma Oficial Mexicana NOM-039- PESC-2003, Pesca responsable de jaiba en aguas de jurisdicción federal del litoral del Océano Pacífico. Especificaciones para su aprovechamiento. Secretaría de Agricultura, Ganadería, Desarrollo Rural, Pesca y Alimentación, México, 9 pp. 


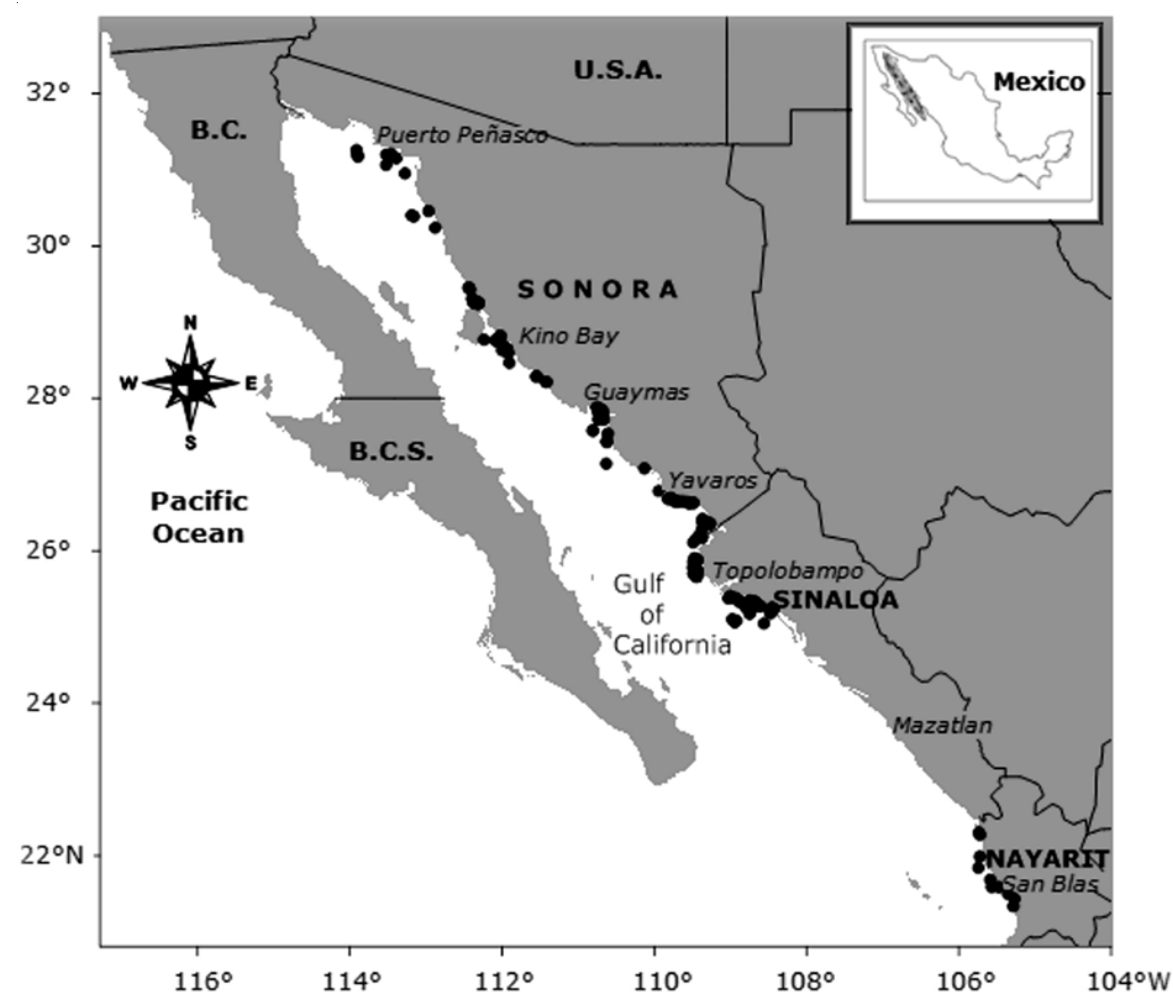

Figure 1. Sampling stations during the 2004-2005 shrimp fishing season in the Gulf of California and main sites where crab capture is recorded / Estaciones de muestreo durante la temporada de pesca camaronera 2004-2005 en el Golfo de California y principales lugares donde se registra la captura de jaiba

$31^{\circ} 24^{\prime} 35^{\prime \prime} \mathrm{N}, 114^{\circ} 22^{\prime} 51^{\prime \prime} \mathrm{W}$, throughout the continental shelf covering the states of Sonora, Sinaloa, and Nayarit (Fig. 1).

The samplings were performed through the 'Onboard Observers' program integrated by 10 technicians, each one on board a shrimp fishing ship from the state of Sonora, México during the 2004-2005 shrimp season that started in August 2004 and finished in March 2005. These ships trawled variable depths (10 to $77 \mathrm{~m}$ ) in a station network located mainly in the fishing areas of commercial shrimp fleet at a speed of $\sim 5.5 \mathrm{~km} \mathrm{~h}^{-1}$ (Fig. 1) from 3 to $5 \mathrm{~h}$. The fishing gear utilized was mixed nets, operating one per band at both sides of the ship; mesh size was $5.71 \mathrm{~cm}$ in the net body and $3.81 \mathrm{~cm}$ in the bag, the official minimum size permitted. Each haul produced approximately $20 \mathrm{~kg}$ of samples without selection; sampling size was determined following standard criteria (Box et al. 2008). The samples were tagged with the proper data of the throw and frozen for later analysis.
Identification and processing of the biological material were performed in the Fisheries Laboratory of Centro de Investigaciones Biológicas del Noroeste (CIBNOR, S.C.) at Guaymas, Sonora. Samples were separated by groups of organisms, and crabs were taxonomically identified using Rathbun (1930) and Hendrickx $(1984,1995)$ keys.

\section{Biometrics, Biometrical RELATIONS, AND SEX PROPORTION}

Each identified specimen was measured in carapace width (CW), which is the distance between the antero-lateral spines with a $0.1-\mathrm{mm}$ precision vernier besides recording its total weight (W) and sex. The existing relationship between the number of females and males in each one of the species and their weight/length relationship were determined by using the potential model $\mathrm{W}=a(\mathrm{CW})^{b}$ where $\mathrm{W}$ is the organism's total weight in grams; CW is the carapace width in millimeters; $a$ is a regression constant; and $b$ is the regression coefficient. The 
regression coefficient was statistically evaluated by the Student's t-test (Zar 1999) to determine the growth type the species showed: if $b=3$, growth is isometric, and if $b$ $\neq 3$, growth is allometric (Ricker 1975).

\section{SPECIES LATITUDINAL AND BATHYMETRIC DISTRIBUTION}

The graphic latitudinal and bathymetric distribution of the 3 crab species were obtained with information of the geographical coordinates and depth where each tow was performed.

\section{SIZE STRUCTURE, GROWTH, AND LONGEVITY}

Size structures were obtained monthly in $5 \mathrm{~mm}-\mathrm{CW}$ intervals of the 3 species and were used to estimate growth adjusted to the von Bertalanffy seasonal model

$$
\mathrm{L}_{\mathrm{t}}=\mathrm{L}_{\infty}\left[1-\mathrm{e}^{\left(-\mathrm{k}\left(\mathrm{t}-\mathrm{t}_{0}\right)+C(\mathrm{~K} / 2 \pi) \sin 2 \pi(t-t s)\right)}\right]
$$

where $\mathrm{L}_{t}$ is carapace width $(\mathrm{CW})$ at time $t ; \mathrm{L}_{\infty}$ is the organism's asymptotic size; $\mathrm{K}$ is growth coefficient (annual); C is growth amplitude; WP is winter point (= ts $+0.5)$, time when growth is minimum; $t$ is summer point (= maximum growth rate); $\mathrm{t}_{0}$ is time when the organism has size zero.

The $\mathrm{L}_{\infty}$ seed values were calculated using the PowellWetherall method (Powell 1979, Wetherall et al. 1987) and K by the New Shepherd's Length Composition Analysis, NSLCA (Shepherd 1987, Pauly \& Arreguín-Sánchez 1995) method. The final parameters were estimated by the size frequency electronic analysis (ELEFAN I). The third parameter equation value $\left(\mathrm{t}_{0}\right)$ was obtained by using the empirical equation proposed by Pauly (1980): $\log \left(-\mathrm{t}_{0}\right)=$ $-0.3922-\left(0.2752 * \log \mathrm{L}_{\infty}\right)-(1.038 \mathrm{k} * \log \mathrm{K})$. The von Bertalanffy equation was used to obtain the growth curves of the 3 crab species. With the purpose of evaluating significant differences in growth between the three species, the growth performance index phi' (Pauly \& Munro 1984) was determined following the equation:

$$
\phi^{\prime}=\log _{10} K+\log _{10} L_{\infty}
$$

Longevity was estimated by the equation proposed by Taylor (1962): $\mathrm{t}_{\max }=3 / \mathrm{K}+\mathrm{t}_{0}$; where $\mathrm{t}_{\max }$ is longevity, $\mathrm{K}$ growth coefficient, and $\mathrm{t}_{0}=$ hypothetical time when the organism has size zero.

\section{RECRUITMENT PATTERN}

To obtain the recruitment pattern (faithful estimate of possible birth dates of the organisms in the captures) the method ELEFAN II (Electronic Length Frequency Analysis II) (Gayanilo et al. 1995) was used. This method shows the longitude frequencies in the captures backwards along the time axis, thus obtaining their likely birth dates.

Mortality (NATURAL, By Fishing, TOtal) AND EXPLOITATION RATE

Natural mortality (M) was estimated using Pauly’s (1984) empirical equation:

$$
\begin{aligned}
\ln M=-(0.01529)-0.279 * \ln \left(L_{\infty}\right) \ldots \\
\ldots+0.6543 * \ln (K)+0.463 * \ln (T)
\end{aligned}
$$

where $\mathrm{L}_{\infty}(\mathrm{mm})$ and $\mathrm{K}$ (annual) von Bertalanffy are equation parameters, and $\mathrm{T}$ is the annual mean temperature of the habitat measured in ${ }^{\circ} \mathrm{C}\left(22^{\circ} \mathrm{C}\right)$. The instant total mortality coefficient (Z) for each species was estimated by the lineal curve method converted to longitude: log $(\mathrm{Ni} / \Delta t i)=\mathrm{a}+\mathrm{b} * t i$ where $N i$ is the number of organisms in longitude $i ; \Delta t i$ is the necessary time for the organism to grow in longitude $i$ from one class to the other; $t$ is the relative age in which the class longitude mean $i$ is reached; and $b$ is an estimate of Z (Gayanilo et al. 1995).

The difference between the instant total mortality coefficient (Z) and that of natural mortality (M) is mortality by fishing (F): $F=Z-M$. While exploitation rate $(E)$ was estimated as: $E=F / Z$ where values higher than 0.5 reflect overexploitation, and lower ones reflect under-exploitation (Sparre \& Venema 1995).

\section{CoMPARING SIZES (COMMERCIAL FLEET/ARTISANAL FISHING)}

We obtained data of biological samplings of Callinectes spp. crabs by artisanal fishing in 3 coast sites off Sonora (Bahía Lobos, Bahía Kino, and Las Guásimas). In these sites (Fig. 1), crabs were captured with Chesapeake type metal traps (60 × $60 \times 40 \mathrm{~cm}$ ) made with $5.7 \times 3.1-\mathrm{cm}$ hexagonal plastic-coated metal mesh with 2 entrances, one or 2 internal chambers, and a bait box in the center of the bottom chamber. Size structures from 2004 to 2005 were obtained, which helped to perform a comparison between the sizes obtained by the shrimp trawl fleet and artisanal fishing. To show significant differences among 
frequency distributions, Pearson's Chi-Square Test $\chi^{2}$ was applied to measure a goodness of fit between the observed and expected values (Zar 1999):

$$
\chi^{2}=\sum_{i=1}^{k} \frac{(o i-e i)^{2}}{e i}
$$

where $o i$ is size frequency of commercial fishing specimens and ei is that of artisanal fishing specimens.

\section{Results}

During 32 monitored trips on board 13 ships from the shrimp fleet based in Guaymas, Sonora, 343 collected samples were analyzed. Their total weight was 2,331 kg with more than 16,900 specimens collected. Fish (69\%) were the most abundant group of the capture, followed by crustaceans (14\%), mollusks (14\%), and echinoderms (3\%).

Of the crustaceans, Callinectes contributed with 1,376 samples, which belonged to 5 species: C. arcuatus (n = 737), C. bellicosus ( $\mathrm{n}=291)$, C. toxotes $(\mathrm{n}=344), C$. robustus $(\mathrm{n}=1)$, and $C$. ruber $(\mathrm{n}=3)$. The following population parameter analyses were only performed for the first 3 species because of the low number of organisms obtained in the 2 last ones.

\section{BIOMETRIC RELATIONSHIPS AND SEX PROPORTION}

The relationship CW/weight of the 3 species (females and males) showed negative allometric growth according to the regression parameters. For $C$. arcuatus $a=0.00020$, $b=2.78, r=0.946, P<0.05$; for $C$. bellicosus $a=0.00021$, $b=2.81, r=0.947, P<0.05$; and for $C$. toxotes $a=0.00083$, $b=2.45, r=0.973, P<0.05$ (Fig. 2).

From these 3 species 1,293 sexed organisms were obtained (Table 1), finding always a greater proportion of females in relation to males throughout the study period: C. arcuatus (5:1), C. bellicosus (2:1), and C. toxotes (6:1).

\section{LATITUDINAL AND BATHYMETRIC DISTRIBUTION}

According to the capture sites of the 3 species, a crammed distribution was observed in all the sampling area with the largest relative abundances concentrated in the northern part of Sinaloa (Topolobampo-Agiabampo), south of Sonora (Las Guásimas-Agiabampo), and north of Nayarit (San Blas) (Fig. 3).

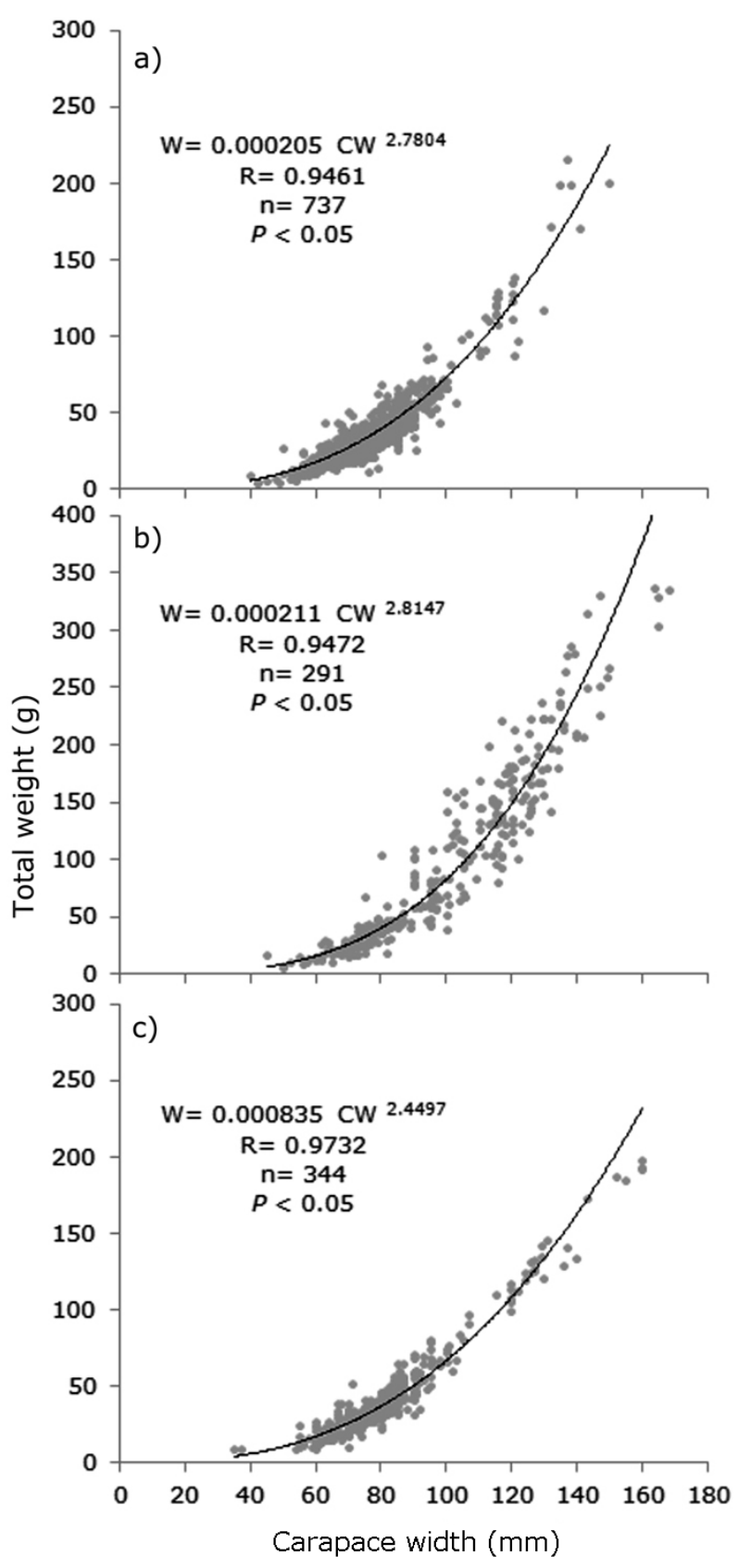

Figure 2. Relationship between carapace width and total weight of both sexes of: a) C. arcuatus, b) C. bellicosus, and c) C. toxotes captured in the eastern Gulf of California from September 2004 to March 2005 / Relación entre el ancho de caparazón y el peso total de: a) C. arcuatus, b) C. bellicosus y c) C. toxotes tomando organismos de ambos sexos, durante septiembre 2004 a marzo 2005, en la parte oriental del Golfo de California 


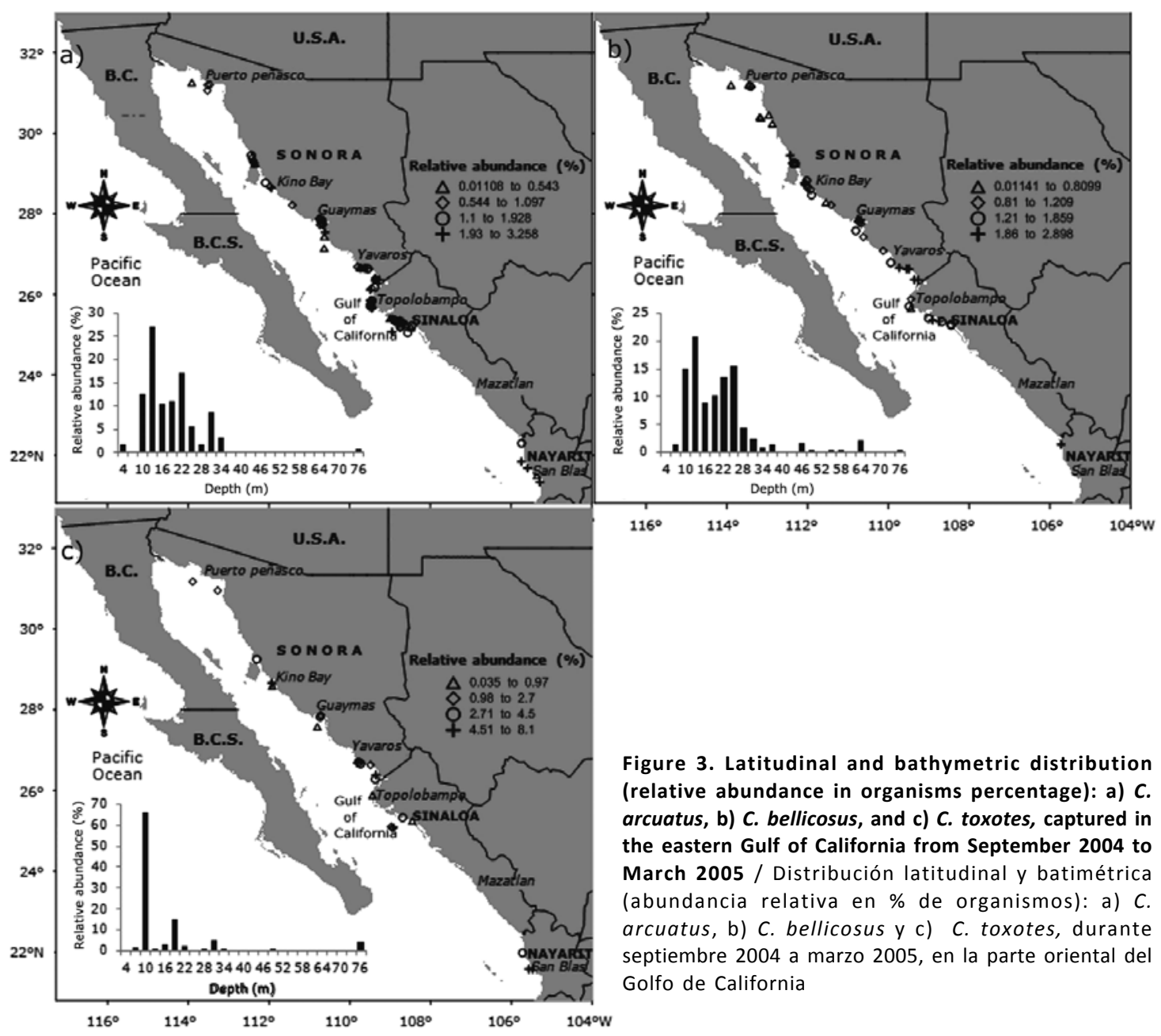

Table 1. Monthly sex proportion analyses of $C$. arcuatus, $C$. bellicosus, and $C$. toxotes, captured in the eastern Gulf of California from September 2004 to March 2005 / Análisis mensual de la proporción de sexos $C$. arcuatus, $C$. bellicosus y $C$. toxotes durante septiembre 2004 a marzo 2005, en la parte oriental del Golfo de California

\begin{tabular}{lcccccc}
\hline & \multicolumn{2}{c}{ C. arcuatus } & \multicolumn{2}{c}{ C. bellicosus } & \multicolumn{2}{c}{ C. toxotes } \\
\hline & Female & Male & Female & Male & Female & Male \\
Sep & 206 & 36 & 63 & 19 & 93 & 5 \\
Oct & 155 & 31 & 60 & 26 & 132 & 33 \\
Nov & 141 & 27 & 58 & 25 & 27 & 1 \\
Dec & 50 & 13 & 9 & 7 & 24 & 0 \\
Jan & 5 & 1 & 0 & 0 & 17 & 10 \\
Feb & 8 & 3 & 1 & 1 & 0 & 0 \\
Mar & 3 & 1 & 0 & 0 & 2 & 0 \\
Total & 568 & 112 & 191 & 78 & 290 & 45 \\
\hline
\end{tabular}




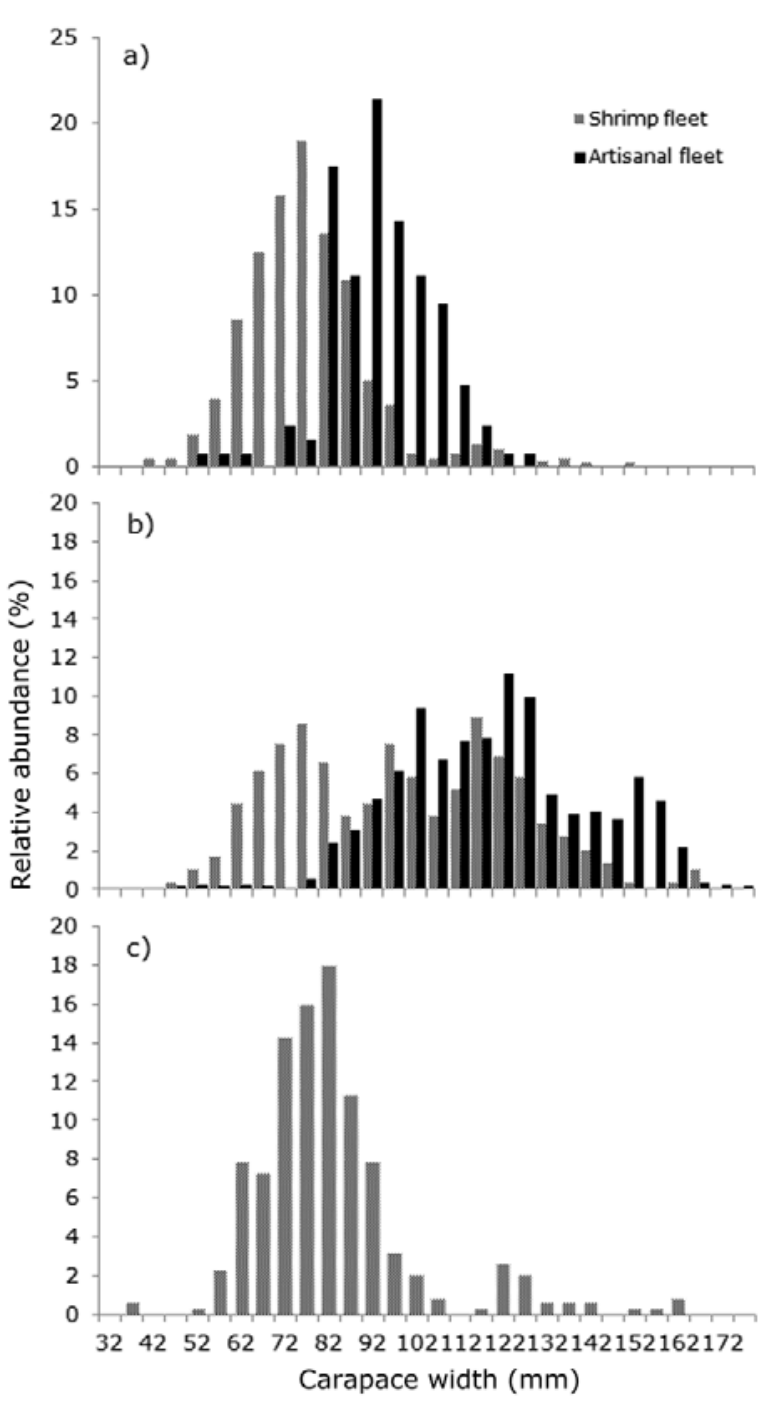

Figure 4. Size distribution: (a) C. arcuatus, (b) C. bellicosus, and (c) C. toxotes, captured in the eastern Gulf of California from 2000 to 2001 (artisanal fishery) and from September 2004 to March 2005 (shrimp fleet) / Distribución de tallas de: a) C. arcuatus, b) C. bellicosus y c) C. toxotes, obtenidas durante 2000 a 2001 (pesca ribereña) y de septiembre 2004 a marzo 2005 (flota camaronera), en la parte oriental del Golfo de California

In general, the 3 species were captured in a range from 10 to $76.8 \mathrm{~m}$ in depth (operation limit of the shrimp fleet); it is unknown if they are distributed at greater depth. However, the highest relative abundances were shown in the range from 10 to $34 \mathrm{~m}$ (Fig. 3).

\section{SIZE STRUCTURES, GROWTH AND LONGEVITY}

The sizes of the 3 species were in the range from 35 to 168

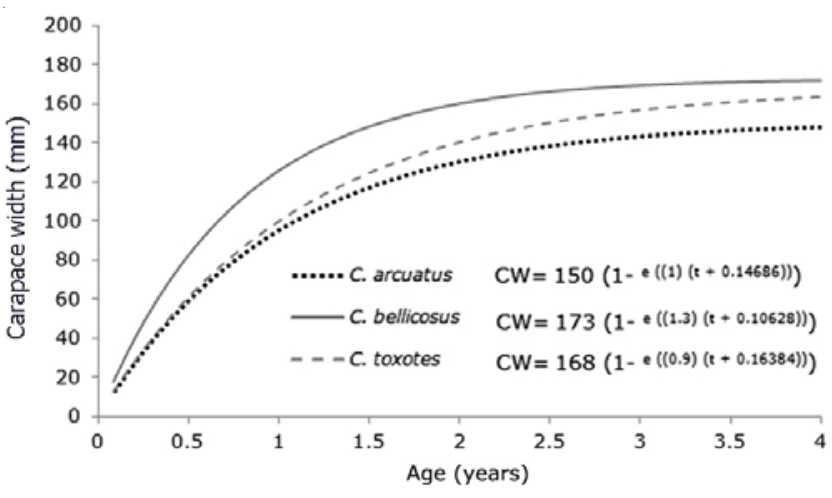

Figure 5. Growth curves of combined sexes of $C$. arcuatus, $C$. bellicosus, and $C$. toxotes, captured in the eastern Gulf of California from September 2004 to March 2005 / Curvas de crecimiento de sexos combinados de $C$. arcuatus, $C$. bellicosus y $C$. toxotes, durante septiembre 2004 a marzo 2005, en la parte oriental del Golfo de California

mm CW during the study period. Those that prevailed were in the range from 62 to $97 \mathrm{~mm}$. In particular, $C$. bellicosus showed the largest sizes (45 to $168 \mathrm{~mm} \mathrm{CW}$ ) while $C$. toxotes showed the smallest ( 35 to $160 \mathrm{~mm}$ ). The size frequency histogram of the 3 species showed a bimodal distribution (Fig. 4).

The growth parameters obtained showed that these 3 species have an accelerated growth $\left(\mathrm{K}_{\text {C.arcuatus }}=1.0, \mathrm{~K}_{C}\right.$. bellicosus $\left.=1.3, \mathrm{~K}_{\text {C.toxotes }}=0.9\right)$, corresponding to their estimated longevity (C. arcuatus 2.85, C. bellicosus 2.19 , and C. toxotes 3.16), which is less than 3 years (Table 2, Fig. 5). The winter point and amplitude of the growth curve were not detected in the model, which means no temperature effects on growth parameters were found in any of the 3 species for the study period. The growth performance index show that $C$. bellicosus has faster growth (phi' $=$ 5.590), followed by $C$. toxotes (phi' $=5.405$ ) and $C$. arcuatus growing slower (phi' $=4.352$ ) than the others.

\section{RECRUITMENT PATTERN}

The recruitment pattern analysis shows a continuous period for the 3 species with a maximum from May to August; in particular, from May to July for C. arcuatus; from July to September for $C$. bellicosus; and from June to August for $C$. toxotes (Table 3).

\section{Mortality (NATURAL, BY Fishing, total) AND EXPLOITATION RATES}

Natural (M), total (Z), by fishing (F) mortality and exploitation (E) estimates obtained for the 3 species are 
Table 2. Growth parameters of 3 crab species reported by different authors in different areas of the Pacific and in this work in the Eastern Gulf of California / Parámetros de crecimiento de las 3 especies de jaibas en diversas áreas del Pacífico realizados por diversos autores y en este trabajo en la parte oriental del Golfo de California

\begin{tabular}{|c|c|c|c|c|c|c|c|c|c|c|}
\hline \multirow[t]{2}{*}{ Area of Study } & \multicolumn{3}{|c|}{ C. arcuatus } & \multicolumn{3}{|c|}{ C. bellicosus } & \multicolumn{3}{|c|}{ C. toxotes } & \multirow[t]{2}{*}{ Author and Year } \\
\hline & $\mathrm{L}_{\infty}$ & $\mathrm{K}$ & $t_{0}$ & $\mathrm{~L}_{\infty}$ & $\mathrm{K}$ & $\mathrm{t}_{0}$ & $\mathrm{~L}_{\infty}$ & $\mathrm{K}$ & $\mathrm{t}_{0}$ & \\
\hline $\begin{array}{l}\text { Coastal Lagoon } \\
\text { Las Guásimas, Sonora }\end{array}$ & $\partial^{\top}+140$ & 0.84 & 0.124 & Ji+ 169 & 0.9 & 0.110 & & & & $\begin{array}{l}\text { Hernández \& Arreola- } \\
\text { Lizárraga (2007) }\end{array}$ \\
\hline $\begin{array}{l}\text { Santa María-La Reforma, } \\
\text { Sinaloa }\end{array}$ & & & & ㅇ 126 & 4.39 & 0.118 & & & & $\begin{array}{l}\text { Rodríguez-Domínguez } \\
\qquad(2012)\end{array}$ \\
\hline $\begin{array}{l}\text { Gulf of Nicoya, } \\
\text { Costa Rica }\end{array}$ & $\delta^{\pi}+142$ & 0.89 & & & & & & & & $\begin{array}{l}\text { Fischer \& Wolff } \\
\text { (2006) }\end{array}$ \\
\hline $\begin{array}{l}\text { Gulf of Tehuantepec, } \\
\text { Chiapas }\end{array}$ & ぷ우 140 & 0.35 & 0.307 & & & & & & & Ramos-Cruz (2008) \\
\hline $\begin{array}{l}\text { Navachiste Bay, } \\
\text { Guasave, Sinaloa }\end{array}$ & $\begin{array}{l}\text { ô156 } \\
\text { \$1 } 141\end{array}$ & $\begin{array}{l}2.00 \\
2.40\end{array}$ & $\begin{array}{l}0.002 \\
0.034\end{array}$ & $\begin{array}{l}\text { O174 } \\
+149\end{array}$ & $\begin{array}{c}2.80 \\
3.7\end{array}$ & $\begin{array}{l}0.450 \\
0.029\end{array}$ & & & & $\begin{array}{l}\text { Salazar et al. } \\
\quad(2003)\end{array}$ \\
\hline $\begin{array}{l}\text { Coastal Lagoon Las } \\
\text { Guásimas, Sonora }\end{array}$ & $30+175$ & 1.00 & & $\delta^{2}+161$ & 1.00 & & & & & Reyes-Benítez (2007) \\
\hline $\begin{array}{l}\text { Coyutlán Lagoon, } \\
\text { Colima }\end{array}$ & 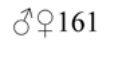 & 1.43 & 0.119 & & & & & & & $\begin{array}{c}\text { Estrada-Valencia } \\
\text { (1999) }\end{array}$ \\
\hline La Paz, B.C.S. & $\begin{array}{l}\text { Ô1 } 182 \\
\text { ᄋ+ } 232\end{array}$ & $\begin{array}{l}0.80 \\
0.50\end{array}$ & $\begin{array}{l}0.160 \\
0.090\end{array}$ & 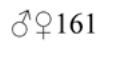 & 0.8 & 0.230 & & & & $\begin{array}{c}\text { Escamilla-Montes } \\
\text { (1998) }\end{array}$ \\
\hline $\begin{array}{l}\text { Mar Muerto Lagoon } \\
\text { Oaxaca-Chiapas }\end{array}$ & ふึ우 152 & 0.63 & 0.109 & J우 180 & 0.68 & 0.180 & ठ̊’ 209 & 0.47 & 0.940 & $\begin{array}{l}\text { Gil \& Sarmiento } \\
\text { (2001) }\end{array}$ \\
\hline Eastern Gulf of California & do+ +150 & 1.00 & 0.146 & d우173 & 1.30 & 0.108 & 구우 168 & 0.90 & 0.163 & This study \\
\hline
\end{tabular}

shown in Table 4. The exploitation rate values do not indicate a significant degree of overexploitation for any of the 3 species $(\mathrm{E}<0.5)$.

\section{SIZE COMPARISON (SHRIMP FLEET/ARTISANAL FISHING)}

To compare sizes, only the distributions of $C$. arcuatus and $C$. bellicosus were used because the third species is not target of commercial fishing by the artisanal fleet in Sonora (where the samplings were performed).

Sizes of 126 organisms of C. arcuatus and 877 of $C$. bellicosus were obtained in the 3 sites off the Sonora coastline. Size ranged from 54 to $126 \mathrm{~mm}$ in CW for the first species and from 49 to $175 \mathrm{~mm}$ for the second one.

The goodness of fit $\chi^{2}$ test showed significant differences between size frequency of $C$. arcuatus and C. bellicosus $\left(\chi_{\mathrm{cal}}^{2}=19.069-\chi_{\mathrm{tab}}^{2}=32.7, P<0.05\right.$, d.f. $=21$ and $\chi_{\text {cal }}^{2}=713-\chi_{\text {tab }}^{2}=36.4, P<0.05$, d.f. = 24) which means that each fleet operates on different population fractions (sizes), albeit with a light overlap between them.
The shrimp fleet extracted mostly small-sized organisms (50-120 mm CW) while the artisanal fleet extracted the organisms in larger sizes (75-155 mm CW) (Fig. 4) likely due to fishing gear selectivity.

\section{Discussion}

In coastal waters of the American continent, 14 Callinectes species have been reported, of which 11 are restricted to the tropics and sub-tropics where the majority are exploited for human consumption (Fischer \& Wolff 2006). In the Mexican Pacific, particularly in the Gulf of California, 3 of these species (C. arcuatus, C. bellicosus, and $C$. toxotes) constitute an important fishery resource in this area. The states of Sinaloa, Sonora, and Baja California Sur (in order of importance) contribute the most to artisanal fishery (Ramírez-Félix et al. 2003, MolinaOcampo et al. 2006).

In our work performed in the Eastern Gulf of California, 5 Callinectes species were found (C. arcuatus, C. 
Table 3. Recruitment pattern analyses of 3 crab species captured in the Gulf of California from September 2004 to March 2005 / Patrón de reclutamiento de las 3 especies de jaibas durante septiembre de 2004 a marzo de 2005, en la parte oriental del Golfo de California

\begin{tabular}{cccc}
\hline & \multicolumn{3}{c}{ \% Recruitment } \\
\cline { 2 - 4 } Month & C. arcuatus & C. bellicosus & C. toxotes \\
\hline Jan & 1 & 1.6 & 0.03 \\
Feb & 3.7 & 4.44 & 0.48 \\
Mar & 6.3 & 4.82 & 1.12 \\
Apr & 12.3 & 6.19 & 1.52 \\
May & 19 & 8.4 & 7.1 \\
Jun & 18.63 & 10.88 & 20.19 \\
Jul & 15.96 & 18.58 & 27.23 \\
Aug & 11.86 & 20.25 & 24.47 \\
Sep & 8.17 & 17.07 & 12.98 \\
Oct & 2.9 & 7.4 & 4.01 \\
Nov & 0.2 & 0.39 & 0.87 \\
Dec & 0 & 0 & 0 \\
\hline
\end{tabular}

bellicosus, C. toxotes, C. robustus, and C. ruber), of which the 3 first ones are the most abundant and match the species commercially captured in this area (MolinaOcampo et al. 2006). Likewise, the areas of greater abundance of these 3 species (Bahía de Kino, Las Guásimas, Agiabampo, Topolobampo, San IgnacioNavachiste, and San Blas) match the main sites where the largest captures are registered in the Gulf of California (Carta Nacional Pesquera 2004) ${ }^{2}$. The third species (C. toxotes) is captured mostly off the southern part of Sinaloa, and its distribution has been reported from the southern Gulf of California down to Colombia (Paul 1982a, CorreaSandoval 1991, Hendrickx 1995). In our work the species were not only captured in the southern Gulf but also in the central and southern parts, extending the limit reported in their distribution area.

Population parameters are important to understand resource management strategies sustainably. For the first time, our work reports population dynamics of $C$. arcuatus, C. bellicosus, and C. toxotes captured by shrimp fleet along the eastern coastline of the Gulf of California in a range from 10 to $77 \mathrm{~m}$ in depth. For the first
Table 4. Mortality and exploitation rates of the 3 Callinectes species captured in the eastern Gulf of California and analyzed from September 2004 to March 2005 / Tasas de mortalidad y explotación de las 3 especies de Callinectes analizadas durante septiembre de 2004 a marzo de 2005, en la parte oriental del Golfo de California

\begin{tabular}{lcccc}
\hline Species & $\mathrm{M}$ & $\mathrm{Z}$ & $\mathrm{F}$ & $\mathrm{E}$ \\
\hline C. arcuatus & 1.5 & 2.9 & 1.4 & 0.48 \\
C. bellicosus & 1.95 & 2.7 & 0.75 & 0.28 \\
C. toxotes & 1.35 & 2.4 & 1.05 & 0.44 \\
\hline
\end{tabular}

2 species, existing reports in the Gulf area are limited to describing these population parameters in depths less than $15 \mathrm{~m}$ where artisanal fleet operates. Literature data (Hendrickx 1983, 1984) report an incidence of Callinectes species at depths ranging from 4 to $40 \mathrm{~m}$. In our work the capture of $C$. arcuatus is reported at depths ranging down to $75 \mathrm{~m}, C$. bellicosus down to $76 \mathrm{~m}$, and $C$. toxotes down to $77 \mathrm{~m}$. These results confirm there is a lack of knowledge on bathymetric distribution and population dynamics of the portion living in deeper areas in the Gulf of California than in those where artisanal fishery operates.

Size frequency distribution offers information on population dynamics in processes such as, growth, mortality, and recruitment, as well as potential migratory population movements. In our work $<95 \mathrm{~mm}$ in CW size structure of C. arcuatus constituted $92 \%$ of the organisms; $<115 \mathrm{~mm}$ of $C$. bellicosus constituted $67 \%$ of the organisms; and $<100 \mathrm{~mm}$ of $C$. toxotes comprised $89 \%$ of the organisms, capture size recommended for each one of these species in the Mexican Pacific coastline (Ramírez-Félix et al. 2003). The 3 species showed similar characteristics in size structure where organisms in sizes higher than $100 \mathrm{~mm}$ in CW were scarce, which could be attributed to the fact that organisms were captured with 50-mm mesh trawling nets that confer low selectivity to this type of fishing gear.

Moreover, by the way this type of net operates at an average speed of $5.5 \mathrm{~km} \mathrm{~h}^{-1}$ (relatively low speed), it is assumed that larger size organisms have the time to avoid the nets or escape (Fisher \& Wolff 2006, López-Martínez et al. 2008). Likewise, significant size distribution differences were found between C. arcuatus and C. bellicosus captured both by artisanal fishery and shrimp

${ }^{2}$ Carta Nacional Pesquera. 2004. Segunda sección, Secretaria de Agricultura, Ganadería, Desarrollo Rural, Pesca y Alimentación. México, D.F. 
fleet, concluding that the shrimp fleet (industrial) extracts mostly organisms of these 2 species in smaller sizes (50$120 \mathrm{~mm}$ CW) while smaller ships (artisanal) extract larger ones (75-155 mm CW). Hernández \& Arreola-Lizárraga (2007) reported size distribution differences in C. arcuatus and $C$. bellicosus obtained from samplings performed with trawling nets in a coastal lagoon (Las Guásimas, Sonora) and in those analyzed by Molina-Ocampo (2001) and Nevárez-Martínez et al. (2003) from commercial captures with traps. To conclude, average sizes captured with trawling nets for $C$. arcuatus and C. bellicosus were 18 and $42 \mathrm{~mm}$, respectively, whereas those coming from commercial captures were 65 and $72 \mathrm{~mm}$, respectively.

These results showed a major abundance of the 3 species from September to November (Table 1) with major incidence of females and large organisms (juveniles and adults), which could suggest a potential species migration to high seas. Arreola-Lizárraga et al. (2003) reported C. arcuatus and $C$. bellicosus inhabit in the inner parts of the coastal lagoons (Las Guásimas, Sonora) during springsummer, and their abundance decreases during autumn. Likewise, it is mentioned that female presence is scarce in the lagoon during this period when adult males are more abundant. Estrada-Valencia (1999) reported male dominance in the captures in another coastal lagoon in the Gulf (Cuyutlán, Colima) during this same period. Considering that reproduction of these organisms is performed at open seas (Molina-Ocampo et al. 2006), it is possible to consider the hypothesis that female dominance at high seas during this period (September-November) responds to a migratory process with reproductive purposes.

The continuous year-round and higher recruit in the summer months (June-August) agrees with that reported by Reyes-Benítez et al. (2007) and at the same time with the reproductive pattern observed by Arreola-Lizárraga \& Hernández-Moreno (2003) and Nevárez-Martínez et al. (2003). It has important impacts for the resource because it coincides with the closed shrimp season (April-August) and with that applied to crab in artisanal fishery. This situation benefits several crab populations as mentioned by López-Martínez et al. (2008, 2011), González-Ochoa et al. (2009), Rábago-Quiroz et al. (2011), and MoralesAzpeitia et al. (2011) for different shrimp bycatch fish species.

The 3 species (C. bellicosus $C$. arcuatus, and $C$. toxotes) showed an allometric growth despite the corresponding values of regression coefficient ' $b$ ' were very close to 3 , whereas the goodness of fit intervals at 95\% and the Student-t test $(3, P<0.05)$ indicated the 3 species tend to grow more in weight than in carapace width (CW). These results disagree with those obtained by Nevárez-Martínez et al. (2003), Hernández \& ArreolaLizárraga (2006), and Reyes-Benítez (2007) who reported an isometric growth for $C$. bellicosus and C. arcuatus. However, they agree with those reported by Paul (1982b), Molina-Ocampo (2001), and Torre et al. (2004), who attributed allometric growth in these species to a phase lag in the optimum biological condition of females due to lower feed rates and more energy loss in the reproduction season. For C. toxotes Gil-López \& Sarmiento-Náfate (2001) reported and isometric growth both in males and females of this species in the Mar Muerto system, OaxacaChiapas, agreeing with the results in our work.

The estimated growth parameters showed that the relative age at which individuals reach maximum growth is between 3 and 4 years for the 3 species, which agree with those reported for $C$. arcuatus and $C$. bellicosus in several areas of the Gulf of California (Estrada-Valencia 1999, Nevárez-Martínez et al. 2003, Reyes-Benítez et al. 2007) and in the Gulf of Nicoya, Costa Rica (Fischer \& Wolff 2006). On the other hand, Gil-López \& SarmientoNáfate (2001) mentioned $C$. toxotes required 4 to 5 years to reach its asymptotic size, which is considered exceptionally long taking into account that crustaceans usually have short life, high growth rate, and when subjected to an intense exploitation rate, they have fewer opportunities to reach their maximum size.

Previous studies on growth estimates for $C$. arcuatus, C. bellicosus, and $C$. toxotes in the Mexican Pacific (Table 2) are based on data from commercial captures with traps where large size organisms dominate (Estrada-Valencia 1999, Gil-López \& Sarmiento-Náfate 2001, Salazar-Navarro et al. 2003, Nevárez-Martínez et al. 2003, Reyes-Benítez et al. 2007). Due to the previous information, absence of small sizes generates a regression range problem and with it an over-estimation (in $\mathrm{L}_{\infty}$ ) or underestimation (in $\mathrm{K}$ ) of growth parameters, which has been documented by López-Martínez et al. (2005) in peneid shrimp and by Rábago-Quiroz et al. (2008) in fish. On the other hand, growth parameter estimates of $C$. arcuatus and $C$. bellicosus performed by Hernández \& Arreola-Lizárraga (2007) with data from samplings captured with trawling nets in a coastal lagoon (Las Guásimas, Sonora) where small sizes dominate generate an underestimation in $\mathrm{L}_{\infty}$. In the case of growth estimates of $C$. arcuatus in the Gulf of Nicoya, Costa Rica (Fischer \& Wolff 2006) and in those 
performed by Ramos-Cruz (2008) in the Gulf of Tehuantepec, Chiapas, they show lower values of $\mathrm{L}_{\infty}$ to those obtained in our work (Table 2), which could be attributed to oceanographic conditions of the area favoring the species to reach larger sizes.

The $\mathrm{F}$ values estimated for the 3 species in our study reveal that the current exploitation they are subjected to by the shrimp fleets is relatively low $(\mathrm{E}<0.48)$. However, given that at least 2 (C. arcuatus and C. bellicosus) of the 3 species analyzed here are target of artisanal fisheries, an analysis considering the combined effect of both fleets should be performed to define crab population health.

In conclusion, some differences in dynamic population parameters were found based on data from commercial captures with traps and those obtained with data of incidental captures from the shrimp trawling fleet. Therefore, an analysis including all the aspects of the population dynamics of these resources is considered necessary with the purpose of proper fishery management.

\section{ACKNowledgments}

This work was based on LLH's thesis with the support of Centro de Investigaciones Biológicas del Noroeste (CIBNOR Project EP12). JLM received funds from SAGARPA-CONACYT (Project 2003-C01-089) and Fundación PRODUCE, Sonora (Project F26-2009-1797). We are grateful to CIBNOR staff in the Fisheries Laboratory at Guaymas, especially to E. Herrera-Valdivia and R. Morales-Azpeitia for all the facilities offered to perform this work and to D. Dorantes for English translation and edition.

\section{LITERATURE CITED}

Arreola-Lizárraga JA, LG Hernández-Moreno, S Hernández-Vázquez, FJ Flores-Verdugo, C LechugaDevezé \& A Ortega-Rubio. 2003. Ecology of Callinectes arcuatus and Callinectes bellicosus (Decapoda: Portunidae) in a coastal lagoon of Northwest Mexico. Crustaceana 76: 651-664.

Box EG, JH Stuart \& WG Hunter. 2008. Estadística para investigadores. Diseño, innovación y descubrimiento, 629 pp. Reverté-Wiley, Barcelona.

Correa-Sandoval PF. 1991. Catálogo y bibliografía de cangrejos (Brachyura) del Golfo de California. En: Comunicaciones Académicas CICESE, pp. 1-117. Ensenada, B.C., México.

Escamilla-Montes MR. 1998. Aspectos de la biología de jaibas del género Callinectes en el estero El Conchalito, Ensenada de La Paz, B.C.S. Tesis de Maestría, Centro
Interdisciplinario de Ciencias Marinas del Instituto Politécnico Nacional, La Paz, B.C.S., México, 96 pp.

Estrada-Valencia A. 1999. Aspectos poblacionales de la jaiba Callinectes arcuatus Ordway 1863, en la laguna de Cuyutlán, Colima, México. Tesis de Maestría, Universidad de Colima, Facultad de Medicina Veterinaria y Zootecnia, Colima, Colima, México, 68 pp.

Fischer S \& M Wolff. 2006. Fisheries assessment of Callinectes arcuatus (Brachyura, Portunidae) in the Gulf of Nicoya, Costa Rica. Fisheries Research 77: 301-311.

Gayanilo FJR, CP Sparre \& D Pauly. 1995. The FAO ICLARM Stock Assessment Tools (FiSAT) User's Guide. FAO Computerized Information Series, Fisheries 8: 1-186.

Gil-López HA \& S Sarmiento-Náfate. 2001. Algunos aspectos biológicos y pesqueros de las jaibas (Callinectes spp.) en el sistema lagunar Mar Muerto, Oaxaca-Chiapas. Documento Técnico, SAGARPA, INAPESCA, CRIP, Salina Cruz, Oaxaca, 41 pp.

González-Ochoa OA, J López-Martínez \& NY HernándezSaavedra. 2009. Population characteristics of spotted rose snapper Lutjanus guttatus caught as shrimp bycatch in the Gulf of California. Interciencia 34: 808-813.

Hendrickx ME. 1983. Studies of the coastal marine fauna of southern Sinaloa, Mexico. Tomo II. The decapod crustaceans of estero El Verde. Anales del Instituto de Ciencias del Mar y Limnología, Universidad Nacional Autónoma de México 11(1): 23-48.

Hendrickx ME. 1984. Estudio de la fauna marina y costera del sur de Sinaloa, México. Tomo III. Clave de identificación de los cangrejos de la Familia Portunidae (Crustacea: Decapoda). Anales del Instituto de Ciencias del Mar y Limnología, Universidad Nacional Autónoma de México 11(1): 1-246.

Hendrickx ME. 1995. Cangrejos. En: Fisher W, F Krupp, W Schneider, C Sommer, KE Carpenter \& VH Niem (eds). Guía FAO para la identificación de especies para los fines de la pesca. Pacífico Centro-Oriental 1, Plantas e invertebrados, pp. 1-646. FAO, Roma.

Hernández L \& A Arreola-Lizárraga. 2007. Estructura de tallas y crecimiento de los cangrejos Calinectes bellicosus y Callinectes arcuatus (Decapoda: Portunidae) en la laguna costera Las Guásimas, México. Revista de Biología Tropical 55(1): 225-233.

López-Martínez J, C Rábago-Quiroz, M NevárezMartínez, J Chávez-Villalva, A García-Juárez \& G Rivera-Parra. 2005. Growth, reproduction, and size at first maturity of the blue shrimp, Litopenaeus stilirostris (Stimpson, 1984) along the east coast of the Gulf of California, Mexico. Fisheries Research 71: 93-102.

López-Martínez J, J Rodríguez-Romero, NY HernándezSaavedra \& E Herrera-Valdivia. 2011. Population parameters of the Pacific flagfin mojarra Eucinostomus currani (Perciformes:Gerreidae) captured by shrimp trawling fishery in the Gulf of California. Revista de Biología Tropical 59: 887-897. 
López-Martínez J, S Hernández-Vázquez, C RábagoQuiroz, E Herrera-Valdivia \& R Morales-Azpeitia. 2008. Efectos ecológicos de la pesca de arrastre de camarón en el Golfo de California. Estado del arte del desarrollo tecnológico de las artes de pesca. En: La situación del sector pesquero en México. Centro de Estudios para el Desarrollo Rural Sustentable y la Soberanía Alimentaria-CEDRSSA, México, pp. 14-45.

Molina-Ocampo RE. 2001. Jaiba del Estado de Sonora Callinectes bellicosus. En: Sustentabilidad y Pesca Responsable en México, Evaluación y Manejo. INAPESCA/SEMARNAP, México, pp. 329-349.

Molina-Ocampo RE, JF Márquez-Farías \& E RamírezFélix. 2006. Jaiba del Golfo de California. En: Sustentabilidad y Pesca Responsable en México. Evaluación y Manejo. INAPESCA/SAGARPA. México, pp. 131-154.

Morales-Azpeitia R, J López-Martínez, J RodríguezRomero \& JT Ponce-Palafox. 2011. Distribución, abundancia y patrón reproductivo de Pseudupeneus grandisquamis Gill 1863 (Perciformes: Mullidae) y Urobatis halleri Cooper 1863 (Rajiformes: Urolophidae) en el Golfo de California. Investigación y Ciencia 52: 3-14.

Nevárez-Martínez MO, J López-Martínez, C CervantesValle, E Miranda-Mier, R Morales-Azpeitia \& ML Anguiano-Carrasco. 2003. Evaluación biológico-pesquera de las jaibas Calinectes bellicosus y Callinectes arcuatus (Brachyura: Decapoda: Portunidae) en las bahías de Guásimas y Lobos, Sonora. En: Hendrickx ME (ed). Contributions to the study of East Pacific Crustaceans 2, pp. 125-138. Instituto de Ciencias del Mar y Limnología, Universidad Nacional Autónoma de México, México.

Paul RKG. 1982a. Abundance, breeding and growth of Callinectes arcuatus Ordway and Callinectes toxotes Ordway (Decapoda: Brachyura: Portunidae) in a lagoon system on the Mexican Pacific Coast. Estuarine Coastal and Shelf Science 14: 13-26.

Paul RKG. 1982b. Observation on the ecology and distribution of swimming crabs of the genus Callinectes (Decapoda: Brachyura: Portunidae) in the Gulf of California, Mexico. Crustaceana 42: 96-100.

Pauly D. 1980. On the interrelationships between natural mortality, growth parameters, and mean environmental temperature in 175 fish stocks. International Council for the Exploration of the Sea 39(2): 175-192.

Pauly D. 1984. Fish population dynamics in tropical water: a manual for use with programmable calculators, 325 pp. International Center for Living Aquatic Resources Management, Manila.

Pauly D \& F Arreguín-Sánchez. 1995. Improving Shepherd's length composition analysis (SLCA) method for growth parameter estimations. NAGA ICLARM Quart 18(4): 3133.

Pauly D \& L Munro. 1984. Once more on growth comparison in fish and vertebrates. Fishbyte 2(1): 1-21.
Pfeiler E, LA Hurtado, LL Knowles, J Torre-Cosío, L Bourrillón-Moreno, JF Márquez-Farías \& G Montemayor-López. 2005. Population genetics of the swimming crab Callinectes bellicosus (Brachyura: Portunidae) from the Eastern Pacific Ocean. Marine Biology 146: 559-569.

Powell DG. 1979. Estimation of mortality and growth parameters from the length frequency of a catch. Rapports et Proces-Verbaux des Reunions CIEM 175: 167-169.

Rábago-Quiroz CH, J López-Martínez, E Herrera-Valdivia, MO Nevárez-Martínez \& J Rodríguez-Romero. 2008. Population dynamics and spatial distribution of flatfish species in shrimp trawl bycatch in the Gulf of California. Hidrobiologica 18: 177-188.

Rábago-Quiroz CH, J López-Martínez, JE Valdez-Holguín \& MO Nevárez-Martínez. 2011. Distribución latitudinal y batimétrica de las especies más abundantes y frecuentes en la fauna acompañante del camarón del Golfo de California, México. Revista de Biología Tropical 59: 255-267.

Ramírez-Félix E, J Singh-Cabanillas, HA Gil-López, S Sarmiento-Náfate, I Salazar, LG Montemayor, JA García-Borbón, G Domínguez \& N Castañeda. 2003. La pesquería de jaiba (Callinectes spp.) en el Pacífico mexicano: diagnóstico y propuesta de regulación, 48 pp. CONAPESCA/INAPESCA, México.

Ramos-Cruz S. 2008. Estructura y parámetros poblacionales de Callinectes arcuatus Ordway, 1863 (Decapoda: Portunidae), en el sistema lagunar La Joya Buenavista, Chiapas, México. Julio a diciembre de 2001. Pan-American Journal of Aquatic Sciences 3(3): 259-268.

Rathbun M. 1930. The cancroids crabs of America of the families Euryalidae, Portunidae, Atlecyclidae, Cancridae and Xanthidae. Bulletin of the United States National Museum 152: 1-609.

Reyes-Benítez E, J López-Martínez, MO Nevárez-Martínez \& R Morales-Azpeitia. 2007. Dinámica poblacional de Callinectes bellicosus (Stimpson, 1859) y Callinectes arcuatus (Ordway, 1863) en Las Guásimas, Sonora, México, durante el periodo 2002 a 2004. En: Contribuciones al Estudio de los Crustáceos del Pacífico Este, Instituto de Ciencias del Mar y Limnología, Universidad Nacional Autónoma de México, México, pp. 17-30.

Ricker WE. 1975. Computation and interpretation of biological statistics of fish populations. Fisheries Research Board of Canada, Bulletin 191: 1-382.

Rodríguez-Domínguez G, SG Castillo-VargasMachuca, R Pérez-González \& EAAragón-Noriega. 2012. Estimation of the individual growth parameters of the Brown crab Callinectes bellicosus (Brachyura, Portunidae) using multimodel approach. Crustaceana 85(1): 55-69.

SAGARPA-CONAPESCA. 2011. Anuario estadístico de pesca 2010, 305 pp. Secretaría de Agricultura, Ganadería, Desarrollo Rural, Pesca y Alimentación, Comisión Nacional de Acuacultura y Pesca, México. 
Salazar-Navarro I, V Macías-Sánchez \& A RamosGonzález. 2003. Estudio biológico pesquero para el manejo sustentable de la pesquería de jaiba Callinectes bellicosus (Stimpson, 1859) y C. arcuatus (Ordway, 1863) en las bahías de Topolobampo, Navachiste, Santa María La Reforma, Ensenada el Pabellón-Altata y Ceuta en las costas de Sinaloa, México. Periodo: enero de 1999 a diciembre de 2001. Documento Técnico, SAGARPA, INAPESCA, CRIP, Mazatlán, Sinaloa, 42 pp.

Shepherd JG. 1987. A weakly parametric method for estimating growth parameters from length composition data. In: Pauly D \& GR Morgan (eds). Length-Based Methods in Fishery Research, pp. 113-119. ICLARM, Safat.

Sparre P \& SC Venema. 1995. Introducción a la evaluación de los recursos pesqueros tropicales. FAO Documento Técnico de Pesca, Parte 1 Manual 306: 1-94.

Taylor CC. 1962. Growth equations with metabolic parameter. International Council for the Exploration of the Sea 27(3): 270-286.

Torre J, L Bourillón \& AH Weaver. 2004. La Pesquería de la jaiba verde (Callinectes bellicosus) en la región de Bahía de Kino y Canal de Infiernillo entre 1998 y 2002. Informe Interno, Comunidad y Biodiversidad, A.C. (COBI), Guaymas, Sonora, México, 48 pp.
Van Engel WA. 1990. Development of the reproductively functional form in the male blue crab, Callinectes sapidus. Bulletin of Marine Science 46: 13-22.

Villarreal-Chávez G. 1992. Algunos aspectos de la biología de Callinectes arcuatus (Crustacea: Decapoda: Portunidae) en el delta del Río Colorado, México. Proceedings of the San Diego Society of Natural History 10: 1-4.

Wetherall JA, J Polovina, S Ralston. 1987. Estimating growth and mortality in steady-state fish stock from lengthfrequency data. In: Pauly D \& GR Morgan (eds). Lengthbased methods in fishery research, pp. 53-74. ICLARM, Safat.

Williams AB. 1974. The swimming crabs of the genus Callinectes (Decapoda, Portunidae). Fishery Bulletin 72: 685-798.

Zar JH. 1999. Biostatistical analysis, 662 pp. Prentice Hall, Upper Saddle River. 